\title{
PERTUMBUHAN DAN HASIL TANAMAN MENTIMUN (Cucumis sativus L) PADA BERBAGAI KOMPOSISI MEDIA TANAM DAN PEMBERIAN MOL BONGGOL PISANG
}

\author{
Abdul Muis ${ }^{1}$, Muhammad Syahril ${ }^{2}$, Murdhiani $^{2}$ \\ ${ }^{1}$ Mahasiswa Program Studi Agroteknologi Fakultas Pertanian Universitas Samudra. ${ }^{2}$ Dosen Program \\ Studi Agroteknologi Fakultas Pertanian Universitas Samudra \\ Email: abdlmuis2130@gmail.com
}

\begin{abstract}
ABSTRAK
Penelitian ini bertujuan untuk melihat pertumbuhan dan hasil tanaman mentimun (Cucumis sativus L) pada berbagai komposisi media tanam dan pemberian MOL bonggol pisang, serta melihat interaksi antara komposisi media tanam dengan pemberian MOL bonggol pisang. Penelitian ini dilakasanakan di Desa Meurandeh Dayah, Kecamatan Langsa Lama, Kota Langsa, pada bulan Agustus sampai September 2020. Penelitian ini menggunakan Rancang Acak Kelompok (RAK) pola fakorial yang terdiri dari 2 faktor : faktor pertama yaitu : komposisi media tanam (M) yang terdiri dari 9 taraf, yaitu: $\mathbf{M}_{1}=$ Tanah + Pupuk Kandang Sapi + Arang Sekam (2:1:1), $\mathbf{M}_{2}=$ Tanah + Pupuk Kandang Sapi + Pasir (2:1:1), $\mathbf{M}_{3}=$ Tanah + Pupuk Kandang Sapi + Cocopeat (2:1:1), $\mathbf{M}_{4}=$ Tanah + Pupuk Kandang Ayam + Arang Sekam (2:1:1), $\mathrm{M}_{5}=$ Tanah + Pupuk Kandang Ayam + Pasir $(2: 1: 1), \mathbf{M}_{6}=$ Tanah + Pupuk Kandang Ayam + Cocopeat $(2: 1: 1), \mathbf{M}_{7}=$ Tanah + Pupuk Kandang Kambing + Arang Sekam (2:1:1), $\mathbf{M}_{8}=$ Tanah + Pupuk Kandang Kambing + Pasir (2:1:1) dan $\mathbf{M}_{9}=$ Tanah + Pupuk Kandang Kambing + Cocopeat (2:1:1). Faktor kedua yaitu : konsentrasi MOL bonggol pisang yang terdiri dari 3 taraf, yaitu: $\mathrm{B}_{0}=0 \mathrm{ml} / 1$ liter air/poly bag, $\mathrm{B}_{1}=150 \mathrm{ml} / 1$ liter air/ poly bag dan $\mathrm{B}_{2}=300 \mathrm{ml} / 1$ liter air/polybag. Parameter yang diamati : tinggi tanaman, panjang buah, diameter buah, produksi per plot. Hasil penelitian menunjukkan bahwa komposisi media tanam berpengaruh nyata terhadap parameter tinggi tanaman, panjang buah, diameter buah, dan produksi per plot. Interaksi perlakuan media tanam dengan MOL bonggol pisang terbaik diperoleh pada perlakuan $\mathrm{M}_{8}=$ Tanah + Pupuk Kandang Kambing + Pasir (2:1:1) dan $\mathrm{B}_{2}=300 \mathrm{ml} / 1$ liter air/poly bag.
\end{abstract}

Kata kunci : Media Tanam, MOL, Mentimun

\section{PENDAHULUAN}

Pengembangan budidaya mentimun mempunyai peranan penting dan memberi sumbansi yang cukup besar terhadap peningkatan taraf hidup petani. Kebutuhan buah mentimun cenderung terus meningkat sejalan dengan pertambahan penduduk. Namun produksi mentimun di Indonesia saat ini masih sangat rendah karena mentimun hanya ditanam sebagai tanaman selingan. (Wijoyo, 2012).

Salah satu usaha peningkatan produksi mentimun adalah pengunaan komposisi media tanam yang tepat. Media tanam yang digunakan adalah tanah, pupuk kandang, arang sekam, pasir dan cocopeat, dengan tujuan memanfaatkan bahan-bahan disekitar untuk dijadikan solusi dalam permasalahan tekstur dan strukur tanah dalam budidaya. Penerapan media tanam dalam budidaya akan lebih efektif terhadap pertumbuhan dan produksi tanaman mentimun jika ditambah dengan pengaplikasian pupuk organik cair, salah satu pupuk organik cair yang dapat digunakan adalah MOL bonggol pisang. MOL adalah larutan hasil fermentasi yang berbahan dasar dari berbagai sumber daya lokal. MOL Bonggol pisang mengandung mikrobia pengurai bahan organik. Mikrobia pengurai tersebut terletak pada bonggol pisang bagian luar maupun bagian dalam. Penerapan berbagai komposisi media tanam dan pengaplikasian MOL bonggol pisang diharapkan dapat meningkatkan kesuburan tanah serta pertumbuhan dan produksi tanaman timun, serta dapat menjadi alternatif dalam membudidayakan timun diareal perkotaan yang memiliki lahan sempit. 


\section{BAHAN DAN METODE PENELITIAN}

Penelitian ini telah dilaksanakan pada bulan Agustus-September 2020 di Gampong Meurandeh Dayah, Kecamatan Langsa Lama, Kota Langsa dengan ketingian tempat 10 mdpl. Adapun alat-alat yang digunakan dalam penelitian ini antara lain : cangkul, parang, meteran, gembor, hand sprayer, ember, tong, alat tulis, papan triplek, tali plastik, timbangan analitik, timbangan manual, jangka sorong, bambu, kamera, baby bag $8 \mathrm{~cm}$ x $9 \mathrm{~cm}$ dan poly bag ukuran $17 \mathrm{~cm} \times 35 \mathrm{~cm}$.

Bahan yang digunakan dalam penelitian ini antara lain : benih timun varietas Mercy F1, pupuk anorganik (pupuk urea, SP-36, KCL), pupuk organik (pupuk kandang sapi, pupuk kandang ayam, pupuk kandang kambing), bonggol pisang, air cucian beras sebagai sumber karbohidrat, air kelapa sebagai sumber protein, gula merah sebagai sumber glukosa, tanah, arang sekam, Cocopeat dan pasir. Penelitian ini menggunakan Rancangan Acak Kelompok (RAK) faktorial dengan dua faktor, yaitu : 1. Faktor komposisi media tanam (M) yang terdiri dari 9 taraf, yaitu : $\mathbf{M}_{1}=$ Tanah + Pupuk Kandang Sapi + Arang Sekam (2:1:1), $\mathbf{M}_{2}=$ Tanah + Pupuk Kandang Sapi + Pasir (2:1:1), $\mathbf{M}_{3}$ $=$ Tanah + Pupuk Kandang Sapi + Cocopeat (2:1:1), $\mathrm{M}_{4}=$ Tanah + Pupuk Kandang Ayam + Arang Sekam (2:1:1), $\mathbf{M}_{5}=$ Tanah + Pupuk Kandang Ayam + Pasir (2:1:1), $\mathbf{M}_{6}=$ Tanah + Pupuk Kandang Ayam + Cocopeat (2:1:1), $\mathrm{M}_{7}=$ Tanah + Pupuk Kandang Kambing + Arang Sekam (2:1:1), $\mathrm{M}_{8}=$ Tanah + Pupuk Kandang Kambing + Pasir (2:1:1), $\mathbf{M}_{9}=$ Tanah + Pupuk Kandang Kambing + Cocopeat (2:1:1). 2.Faktor konsentrasi MOL bonggol pisang (B) yang terdiri dari 3 taraf, yaitu : $\mathrm{B}_{0}=$ $0 \mathrm{ml} / 1$ liter air, $\mathrm{B}_{1}=150 \mathrm{ml} / 1$ liter air, $\mathrm{B}_{2}=300 \mathrm{ml} / 1$ liter air. Parameter yang diamati adalah tinggi tanaman, panjang buah, diameter buah, dan produksi per plot.

\section{HASIL DAN PEMBAHASAN}

\section{Pengaruh Komposisi Media Tanam}

\section{Tinggi Tanaman}

Rata-rata tinggi tanaman mentimun pada umur 14, 21 dan 28 HST akibat pemberian komposisi media tanam disajikan pada Tabel 1.

Tabel1.Rata-rata tinggi tanaman mentimun umur 14, 21 dan 28 HST akibat perbedaan komposisi media tanam.

\begin{tabular}{cccc}
\hline \multirow{2}{*}{ Perlakuan } & \multicolumn{3}{c}{ Tinggi Tanaman (cm) pada Umur } \\
\cline { 2 - 4 } & $14 \mathrm{HST}$ & $21 \mathrm{HST}$ & $28 \mathrm{HST}$ \\
\hline $\mathrm{M}_{1}$ & $31,53 \mathrm{~b}$ & $73,19 \mathrm{~b}, 25 \mathrm{bc}$ \\
$\mathrm{M}_{2}$ & $31,78 \mathrm{~b}$ & $73,99 \mathrm{bc}$ & $153,68 \mathrm{~cd}$ \\
$\mathrm{M}_{3}$ & $30,63 \mathrm{a}$ & $71,54 \mathrm{a}$ & $146,97 \mathrm{a}$ \\
$\mathrm{M}_{4}$ & $32,78 \mathrm{c}$ & $75,53 \mathrm{~cd}$ & $151,91 \mathrm{~b}$ \\
$\mathrm{M}_{5}$ & $33,12 \mathrm{c}$ & $76,08 \mathrm{~d}$ & $157,42 \mathrm{e}$ \\
$\mathrm{M}_{6}$ & $32,63 \mathrm{c}$ & $77,82 \mathrm{e}$ & $154,43 \mathrm{~d}$ \\
$\mathrm{M}_{7}$ & $35,87 \mathrm{f}$ & $82,56 \mathrm{f}$ & $167,04 \mathrm{~h}$ \\
$\mathrm{M}_{8}$ & $34,13 \mathrm{~d}$ & $81,70 \mathrm{f}$ & $165,13 \mathrm{~g}$ \\
$M_{9}$ & $35,10 \mathrm{e}$ & $81,53 \mathrm{f}$ & $163,56 \mathrm{f}$ \\
\hline $\mathrm{BNJ}_{0,05}$ & 0,73 & 1,60 & 1,43 \\
\hline
\end{tabular}

Keterangan : Angka yang diikuti oleh huruf yang sama pada kolom yang sama berbeda tidak nyata pada uji $\mathrm{BNJ}_{0,05 \%}$.

Tabel 1 menunjukkan bahwa pemberian komposisi media tanam terbaik terhadap tinggi tanaman mentimun pada umur 14, 21 dan 28 HSTdidapatkan pada perlakuan $\mathrm{M}_{7}$. Hasil uji $\mathrm{BNJ}_{0,05}$ umur 14 dan 28 HST pada perlakuan $\mathrm{M}_{7}$ berbeda nyata dengan perlakuan lainya. Pada umur $21 \mathrm{HST}$ tinggi tanaman perlakuan $\mathrm{M}_{7}$ berbeda tidak nyata dengan perlakuan $\mathrm{M}_{8}$ dan $\mathrm{M}_{9}$ namun berbeda nyata dengan perlakuan $\mathrm{M}_{1}, \mathrm{M}_{2}, \mathrm{M}_{3}, \mathrm{M}_{4}, \mathrm{M}_{5}$, dan $\mathrm{M}_{6}$. 
Hal ini diduga karena pakan yang dikonsumsi ternak kambing lebih sering diberi pakan ampas tahu yang kaya akan protein, sehingga dapat meningkatkan kualitas hara $\mathrm{N}$ pada kotorannya. Sesuai dengan pendapat Madjid (2010), pakan yang dikonsumsi hewan ternak akan diubah menjadi bahan yang tersedia bagi tanaman, jika pakan yang diberikan banyak mengandung protein, maka kotorannya akan banyak mengandung N. Menurut Wiryanta dan Bernadius (2002), menyatakan kandungan hara $\mathrm{N}$ sapi 2,03\%, ayam 2,08\% dan kambing 2,17\%. Sedangkan arang sekam memiliki kandungan hara $\mathrm{K}$ tinggi yang mampu mengoptimalkan proses fotosintesis, sehingga membantu pertumbuhan tinggi tanaman mentimun. Penambahan arang sekam dapat meningkatkan pertumbuhan tinggi semai jabon sebesar 18,31\% -28,36\% (Suprianto 2010). Menurut Kusuma dan Saptaningsih (2013), yang menyatakan bahwa arang sekam mengandung N 0,18\%, P 0,28\% dan K 0,30\%.

\section{Panjang Buah}

Rata-rata panjang buah pada tanaman mentimun akibat perbedaan komposisi media tanam disajikan pada Tabel 2. Tabel 2 menunjukkan bahwa pemberian komposisi media tanam terbaik terhadap panjang buah tanaman mentimun pada panen ke 1, 2 dan 3 didapatkan pada perlakuan $\mathrm{M}_{8}$. Secara hasil uji $\mathrm{BNJ}_{0,05}$ panen ke 1 pada perlakuan $\mathrm{M}_{8}$ berbeda tidak nyata dengan perlakuan $\mathrm{M}_{9}$, namun berbeda nyata dengan perlakuan $\mathrm{M}_{1}, \mathrm{M}_{2}, \mathrm{M}_{3}, \mathrm{M}_{4}, \mathrm{M}_{5}, \mathrm{M}_{6}$ dan $\mathrm{M}_{7}$. Pada panen ke 2 perlakuan $M_{8}$ berbeda nyata dengan perlakuan lainnya. Selanjutnya panen ke 3 perlakuan $M_{8}$ berbeda tidak nyata dengan perlakuan $M_{7}$, namun berbeda nyata dengan perlakuan $M_{1}, M_{2}, M_{3}, M_{4}, M_{5}, M_{6}$, dan $M_{9}$.

Tabel 2. Rata-rata panjang buah tanaman mentimun akibat perbedaan komposisi media tanam.

\begin{tabular}{cccc}
\hline \multirow{2}{*}{ Perlakuan } & \multicolumn{3}{c}{ Panjang Buah $(\mathrm{cm})$ pada Panen ke- } \\
\cline { 2 - 4 } & 1 & 2 & 3 \\
\hline $\mathrm{M}_{1}$ & $17,98 \mathrm{~b}$ & $18,23 \mathrm{ab}$ & $17,61 \mathrm{ab}$ \\
$\mathrm{M}_{2}$ & $18,64 \mathrm{bc}$ & $18,97 \mathrm{c}$ & $17,93 \mathrm{ab}$ \\
$\mathrm{M}_{3}$ & $17,73 \mathrm{a}$ & $17,82 \mathrm{a}$ & $17,01 \mathrm{a}$ \\
$\mathrm{M}_{4}$ & $19,28 \mathrm{~cd}$ & $18,62 \mathrm{bc}$ & $17,35 \mathrm{a}$ \\
$\mathrm{M}_{5}$ & $20,15 \mathrm{de}$ & $19,80 \mathrm{~d}$ & $18,53 \mathrm{bc}$ \\
$\mathrm{M}_{6}$ & $18,74 \mathrm{bc}$ & $18,16 \mathrm{ab}$ & $17,73 \mathrm{ab}$ \\
$\mathrm{M}_{7}$ & $20,20 \mathrm{e}$ & $20,48 \mathrm{f}$ & $19,54 \mathrm{de}$ \\
$\mathrm{M}_{8}$ & $21,38 \mathrm{f}$ & $21,60 \mathrm{~g}$ & $20,23 \mathrm{e}$ \\
$\mathrm{M}_{9}$ & $20,53 \mathrm{ef}$ & $20,50 \mathrm{f}$ & $19,03 \mathrm{~cd}$ \\
\hline BNJ $_{0,05}$ & 0,92 & 0,59 & 1,00 \\
\hline
\end{tabular}

Keterangan : Angka yang diikuti oleh huruf yang sama pada kolom yang sama berbeda tidak nyata pada uji $\mathrm{BNJ}_{0,05} \%$.

Hal ini diduga pemberian pupuk kandang kambing mampu menyediakan unsur hara yang cukup dan seimbang. Kandungan hara K pada pupuk kandang kambing mampu menyempurnakan panjang buah yang dihasilkan. Hal ini sesuai dengan pendapat Ghani (2002). Dengan adanya kalium yang tersedia maupun yang diberikan dalam bentuk pupuk berpengaruh terhadap proses fotosintesis yang dapat merubah karbohidrat menjadi protein, sehingga pertumbuhan akan lebih efektif termasuk dalam penambahan panjang dan diameter buah. Penggunaan campuran pasir dalam media tanam membuat porositas dan aerasi dalam media tanam menjadi lebih baik, sehingga mempermudah akar menyerap mineral dan unsur hara yang terdapat pada pupuk kandang kambing.

\section{Diameter Buah}

Rata-rata diameter buah pada tanaman mentimun akibat pemberian komposisi media tanam disajikan pada Tabel 3. Tabel 3 menunjukkan bahwa pemberian komposisi media tanam terbaik terhadap diameter buah pada panen ke 1, 2 dan 3 adalah perlakuan $\mathrm{M}_{8}$. Secara uji $\mathrm{BNJ}_{0,05}$ pada panen 
ke 1 dan ke 2 perlakuan $M_{8}$ tidak berbeda nyata dengan perlakuan $M_{5}$ dan $M_{9}$, namun berbeda nyata dengan perlakuan $M_{1}, M_{2}, M_{3}, M_{4}, M_{6}$ dan $M_{7}$. Pada panen ke 3 perlakuan $M_{8}$ tidak berbeda nyata dengan perlakuan $M_{9}$ namun berbeda nyata dengan perlakuan $M_{1}, M_{2}, M_{3}, M_{4}, M_{5}, M_{6}$ dan $M_{7}$.

Tabel 3. Rata-rata diameter buah tanaman mentimun akibat perbedaan komposisi media tanam.

\begin{tabular}{cccc}
\hline \multirow{2}{*}{ Perlakuan } & \multicolumn{3}{c}{ Diameter Buah $(\mathrm{cm})$ pada Panen ke- } \\
\cline { 2 - 4 } & 1 & 2 & 3 \\
\hline $\mathrm{M}_{1}$ & $4,25 \mathrm{a}$ & $4,23 \mathrm{a}$ & $3,91 \mathrm{a}$ \\
$\mathrm{M}_{2}$ & $4,28 \mathrm{a}$ & $4,28 \mathrm{a}$ & $4,05 \mathrm{ab}$ \\
$\mathrm{M}_{3}$ & $4,13 \mathrm{a}$ & $4,18 \mathrm{a}$ & $3,93 \mathrm{a}$ \\
$\mathrm{M}_{4}$ & $4,64 \mathrm{~b}$ & $4,51 \mathrm{~b}$ & $4,27 \mathrm{c}$ \\
$\mathrm{M}_{5}$ & $4,91 \mathrm{de}$ & $4,97 \mathrm{~cd}$ & $4,46 \mathrm{~d}$ \\
$\mathrm{M}_{6}$ & $4,68 \mathrm{bc}$ & $4,66 \mathrm{~b}$ & $4,23 \mathrm{bc}$ \\
$\mathrm{M}_{7}$ & $4,84 \mathrm{~cd}$ & $4,83 \mathrm{c}$ & $4,60 \mathrm{de}$ \\
$\mathrm{M}_{8}$ & $5,08 \mathrm{e}$ & $5,12 \mathrm{~d}$ & $4,93 \mathrm{f}$ \\
$\mathrm{M}_{9}$ & $5,04 \mathrm{e}$ & $5,08 \mathrm{~d}$ & $4,77 \mathrm{ef}$ \\
\hline $\mathrm{BNJ}_{0,05}$ & 0,19 & 0,15 & 0,18 \\
\hline
\end{tabular}

Keterangan : Angka yang diikuti oleh hurup yang sama pada kolom yang sama berbeda tidak nyata pada uji $\mathrm{BNJ}_{0,05} \%$.

Hal ini diduga pupuk kandang kambing mampu mengikat unsur hara dan menyediakan unsur hara K yang tinggi. Hal ini sesuai dengan pendapat Soegiman (2002) bahwa ketersediaan kalium yang cukup pada tanaman akan meningkatkan kuantitas dan kualitas hasil tanaman, hal ini berhubungan dengan panjang buah, diameter buah dan berat buah pada tanaman mentimun.

Porositas media tanamn yang tinggi akibat campuran pasir mampu membuat pergerakan dan perkembangan akar lebih leluasa, sehingga penyerapan unsur hara yang terdapat pada pupuk kandang kambing lebih optimal. Sesuai dengan pendapat Campbell (2003), mengatakan bahwa tanah yang poros mendukung perkembangan akar menembus masuk ke dalam tanah menjadikan akar menyerap hara semakin banyak sehingga dapat meningkatkan hasil tanaman.

\section{Produksi per Plot}

Rata-rata produksi perplot pada tanaman mentimun akibat pemberian komposisi media tanam disajikan pada Tabel 4.

Tabel 4. Rata-rata produksi perplot tanaman mentimun akibat perbedaan komposisi media tanam.

\begin{tabular}{cc}
\hline Perlakuan & Produksi per Plot $(\mathrm{kg})$ \\
\hline $\mathrm{M}_{1}$ & $1,49 \mathrm{~b}$ \\
$\mathrm{M}_{2}$ & $1,56 \mathrm{c}$ \\
$\mathrm{M}_{3}$ & $1,43 \mathrm{a}$ \\
$\mathrm{M}_{4}$ & $1,71 \mathrm{~d}$ \\
$\mathrm{M}_{5}$ & $1,98 \mathrm{f}$ \\
$\mathrm{M}_{6}$ & $1,89 \mathrm{e}$ \\
$\mathrm{M}_{7}$ & $1,97 \mathrm{f}$ \\
$\mathrm{M}_{8}$ & $2,16 \mathrm{~h}$ \\
$\mathrm{M}_{9}$ & $2,04 \mathrm{~g}$ \\
\hline $\mathrm{BNJ}_{0,05}$ & 0,05 \\
\hline
\end{tabular}

Keterangan : Angka yang diikuti oleh hurup yang sama pada kolom yang samaberbeda tidak nyata pada uji $\mathrm{BNJ}_{0,05} \%$.

Tabel 4 menunjukkan bahwa produksi per plot tertinggi terdapat pada perlakuan $\mathrm{M}_{8}$, dari hasil uji $\mathrm{BNJ}_{0,05}$ berbeda nyata dengan semua perlakuan. Hal ini diduga selain memiliki unsur hara yang berimbang, pupuk kandang kambing juga memiliki kemampuan mengikat unsur hara, menahan air 
tanah, meningkatkan kapasitas tukar kation didalam media tanam. Hal ini sesuai dengan pernyataan Hakim dkk (2006), yang mengatakan bahwa pemberian pupuk kandang kambing dapat meningkatkan kemampuan tanah menahan air, merangsang granulasi, memantapkan agregat tanah, menurunkan plastisitas dan kohesi tanah. Pemberian pupuk kandang kambing juga mampu meningkatkan KTK tanah, mengikat unsur N, P, S dalam bentuk organik sehingga terhindar dari pencucian. Menurut Supriyanto dkk (2010), pasir sering digunakan sebagai media tanam alternatif untuk menggantikan fungsi tanah. Namun pasir memiliki pori-pori berukuran besar (pori-pori makro), substitusi atau penambahan bahan organik yang bersifat menahan air dapat memperbaiki sifat pasir tersebut.

\section{Tinggi Tanaman}

\section{Pengaruh Konsentrasi MOL Bonggol Pisang}

Rata-rata tinggi tanaman mentimun akibat dosis MOL bonggol pisang disajikan pada Tabel 5.

Tabel 5. Rata-rata tinggi tanaman mentimun 14, 21 dan 28 HST akibat dosis MOL monggol pisang.

\begin{tabular}{cccc}
\hline \multirow{2}{*}{ Perlakuan } & \multicolumn{3}{c}{ Tinggi Tanaman $(\mathrm{cm})$ pada Umur ke- } \\
\cline { 2 - 4 } & 14 & 21 & 28 \\
\hline $\mathrm{B}_{0}$ & $32,75 \mathrm{a}$ & $75,22 \mathrm{a}$ & $153,65 \mathrm{a}$ \\
$\mathrm{B}_{1}$ & $32,98 \mathrm{a}$ & $77,01 \mathrm{a}$ & $156,94 \mathrm{~b}$ \\
$\mathrm{~B}_{2}$ & $33,85 \mathrm{~b}$ & $79,12 \mathrm{~b}$ & $159,25 \mathrm{~b}$ \\
\hline $\mathrm{BNJ}_{0,05}$ & 0,91 & 2,00 & 2,42
\end{tabular}

Keterangan : Angka yang diikuti oleh hurup yang sama pada kolom yang sama berbeda tidak nyata pada uji $\mathrm{BNJ}_{0,05} \%$.

Tabel 5 menunjukkan bahwa tinggi tanaman mentimun tertinggi terdapat pada perlakuan $B_{2}$. Secara uji $\mathrm{BNJ}_{0,05}$ pada umur ke 14 dan 21 berbeda nyata dengan perlakuan $\mathrm{B}_{0}$ dan $\mathrm{B}_{1}$ pada umur ke 28 berpengaruh nyata pada perlakuan $\mathrm{B}_{0}$, namun tidak berpengaruh nyata pada perlakuan $\mathrm{B}_{1}$. Hal ini diduga karena MOL bonggol pisang memiliki mikroorganisme pengurai bahan organik yang banyak dan kaya akan hara $\mathrm{N}$ sehingga mampu merangsang pertumbuhan tinggi tanaman mentimun. Menurut Setia Ningsih (2009), mikrobia pada bonggol pisang kepok berperan dalam masa pertumbuhan vegetatif tanaman dan tanaman toleran terhadap penyakit. Menurut Mapegau (2010), menyatakan bahwa unsur $\mathrm{N}$ berfungsi dalam meningkatkan jumlah klorofil, jika unsur $\mathrm{N}$ tersedia dalam jumlah yang cukup maka akan meningkatkan laju fotosintesis dan terbentuknya fotosintat.

\section{Panjang Buah}

Rata-rata panjang buah pada tanaman mentimun akibat dosis MOL bonggol pisang disajikan pada Tabel 6. Tabel 6 menunjukkan panjang buah tanaman mentimun terbaik terdapat pada perlakuan $\mathrm{B}_{2}$, secara uji $\mathrm{BNJ}_{0,05}$ perlakuan $\mathrm{B}_{2}$ pada panen ke-1 dan 2 berbeda nyata dengan perlakuan $\mathrm{B}_{0}$ dan $\mathrm{B}_{1}$, namun pada panen ke-3 berpengaruh tidak nyata pada perlakuan $\mathrm{B}_{0}$ dan $\mathrm{B}_{1}$.

Tabel 6. Rata-rata panjang puah tanaman mentimun akibat dosis MOL bonggol pisang

\begin{tabular}{cccc}
\hline \multirow{2}{*}{ Perlakuan } & \multicolumn{3}{c}{ Panjang Buah $(\mathrm{cm})$ pada Panen ke- } \\
\cline { 2 - 4 } & 1 & 2 & 3 \\
\hline $\mathrm{B}_{0}$ & $37,92 \mathrm{a}$ & $18,72 \mathrm{a}$ & $17,92 \mathrm{a}$ \\
$\mathrm{B}_{1}$ & $38,51 \mathrm{a}$ & $19,24 \mathrm{a}$ & $17,96 \mathrm{ab}$ \\
$\mathrm{B}_{2}$ & $39,99 \mathrm{~b}$ & $20,10 \mathrm{~b}$ & $19,12 \mathrm{ab}$ \\
\hline $\mathrm{BNJ}_{0,05}$ & 1,18 & 0,76 & 1,28 \\
\hline
\end{tabular}

Keterangan : Angka yang diikuti oleh hurup yang sama pada kolom yang sama berbeda tidak nyata pada uji

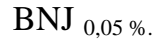


Hal ini diduga karena asam fenolat yang terkandung di dalam MOL bonggol pisang membantu meningkatkan ketersediaan hara $\mathrm{P}$ tanah yang berperan dalam meningkatkan perkembangan buah Suhastyo (2011), menyatakan bahwa di dalam bonggol pisang mengandung asam fenolat yang tinggi, membantu pengikatan ion-ion $\mathrm{Al}$, Fe dan $\mathrm{Ca}$ sehingga membantu meningkatkan ketersediaan hara $\mathrm{P}$ tanah yang berguna pada proses pembangunan dan pembentukan buah.

\section{Diameter Buah}

Rata-rata diameter buah pada tanaman mentimun akibat dosis MOL bonggol pisang disajikan pada Tabel 7.

Tabel 7. Rata-rata diameter buah tanaman mentimun akibat dosis MOL bonggol pisang.

\begin{tabular}{cccc}
\hline \multirow{2}{*}{ Perlakuan } & \multicolumn{3}{c}{ Diameter Buah $(\mathrm{cm})$ pada Panen ke- } \\
\cline { 2 - 4 } & 1 & 2 & 3 \\
\hline $\mathrm{B}_{0}$ & $4,54 \mathrm{a}$ & $4,50 \mathrm{a}$ & $4,12 \mathrm{a}$ \\
$\mathrm{B}_{1}$ & $4,63 \mathrm{ab}$ & $4,58 \mathrm{a}$ & $4,31 \mathrm{a}$ \\
$\mathrm{B}_{2}$ & $4,79 \mathrm{~b}$ & $4,85 \mathrm{~b}$ & $4,62 \mathrm{~b}$ \\
\hline $\mathrm{BNJ}_{0,05}$ & 0,24 & 0,20 & 0,23
\end{tabular}

Keterangan : Angka yang diikuti oleh hurup yang sama pada kolom yang sama berbeda tidak nyata pada uji $\mathrm{BNJ}_{0,05} \%$.

Tabel 7 menunjukkan diameeter buah tanaman mentimun terbaik terdapat pada perlakuan $\mathrm{B}_{2}$ dimana secara uji $\mathrm{BNJ}_{0,05}$ pada panen ke 1 berbeda nyata dengan perlakuan $\mathrm{B}_{0}$ namun tidak berbed nyata pada perlakuan $B_{1}$. Pada panen ke 2 dan 3 berbeda nyata dengan perlakuan $B_{0}$ dan $B_{1}$. Hal ini diduga karena kandungan unsur hara yang lengkap dan berimbang didalam MOL bonggol pisang mampu merangsang perkembangan buah, sehingga berpengaruh terhadap diameter tanaman mentimun. Hasilpenelitian yang dilakukan oleh Suhastyo (2011), menjelaskan bahwa bonggol pisang kaya akan unsur hara kalium yang berperan dalam membantu dalam menyuplai karbohidrat dan protein yang digunakan dalam pembentukan dan pembesaran buah.

\section{Produksi per Plot}

Rata-rata produksi per plot tanaman mentimun akibat dosis MOL bonggol pisang disajikan pada Tabel 8. Tabel 8 menunjukkan produksi per plot tanaman mentimun tertinggi terdapat pada perlakuan $\mathrm{B}_{2}$ dimana secara uji $\mathrm{BNJ}{ }_{0,05}$ berbeda nyata dengan perlakuan $\mathrm{B}_{0}$ dan $\mathrm{B}_{1}$. Hal ini diduga karena bahan organik di dalam media tanam terdekomposisi dengan baik oleh mikroorganisme yang terdapat didalam MOL bonggol pisang, menyebabkan nutrisi yang terdapat didalam bahan organik dapat tersedia sehingga berpengaruh terhadap produksi tanamam mentimun.Sesuaidengan Agustina (2008), yang menyebutkan bahwa aktivitas mikroorganisme pada bahan organik (larutan MOL) akan menghasilkan hormon-hormon pertumbuhan seperti auksin dan giberelin yang mana hormon tersebut dapat memacu pertumbuhan dan perkembangan generatif tanaman.

Tabel 8. Rata-rata produksi perplot tanaman mentimun akibat dosis MOL bonggol pisang.

\begin{tabular}{cc}
\hline Perlakuan & Prduksi per Plot $(\mathrm{kg})$ \\
\hline $\mathrm{B}_{0}$ & $1,68 \mathrm{a}$ \\
$\mathrm{B}_{1}$ & $1,77 \mathrm{~b}$ \\
$\mathrm{~B}_{2}$ & $1,96 \mathrm{c}$ \\
\hline BNJ $_{0,05}$ & 0,06
\end{tabular}

Keterangan : Angka yang diikuti oleh hurup yang sama berbeda tidak nyata pada uji $\mathrm{BNJ}_{0,05} \%$. 


\section{Interaksi Akibat Pengaruh Komposisi Media Tanam Dan Konsentrasi MOL Bonggol Pisang}

\section{Tinggi Tanaman}

Data hasil analisis ragam pengamatan tinggi tanaman mentimun akibat interaksi perlakuan antara pemberian berbagai komposisi media tanam dengan dosis MOL bonggol pisang berpengaruh nyata pada umur 28 HST disajikan pada Tabel 9.

Tabel 9. Rata-rata tinggi tanaman mentimun akibat interaksi perlakuan antara pemberian berbagai komposisi media tanam dengan dosis MOL bonggol pisang pada umur 14, 21 dan $28 \mathrm{HST}$.

\begin{tabular}{|c|c|c|c|}
\hline \multirow{2}{*}{$\begin{array}{c}\text { Perlakuan } \\
\text { Kombinasi }\end{array}$} & \multicolumn{3}{|c|}{ rata-rata tinggi tanaman $(\mathrm{cm})$ pada umur ke- } \\
\hline & 14 HST & $21 \mathrm{HST}$ & $28 \mathrm{HST}$ \\
\hline $\mathrm{M}_{1} \mathrm{~B}_{0}$ & 31,55 & 70,68 & $150,38 \mathrm{bcd}$ \\
\hline $\mathrm{M}_{1} \mathrm{~B}_{1}$ & 30,25 & 72,95 & $151,00 \mathrm{bcd}$ \\
\hline $\mathrm{M}_{1} \mathrm{~B}_{2}$ & 32,78 & 75,95 & $155,38 \mathrm{~d}-\mathrm{g}$ \\
\hline $\mathrm{M}_{2} \mathrm{~B}_{0}$ & 30,98 & 72,13 & $151,75 \mathrm{~b}-\mathrm{e}$ \\
\hline $\mathrm{M}_{2} \mathrm{~B}_{1}$ & 31,45 & 73,73 & $152,23 \mathrm{~b}-\mathrm{e}$ \\
\hline $\mathrm{M}_{2} \mathrm{~B}_{2}$ & 32,90 & 76,13 & 157,05 e-h \\
\hline $\mathrm{M}_{3} \mathrm{~B}_{0}$ & 29,90 & 69,98 & $143,40 \mathrm{a}$ \\
\hline $\mathrm{M}_{3} \mathrm{~B}_{1}$ & 30,40 & 72,95 & $146,93 \mathrm{ab}$ \\
\hline $\mathrm{M}_{3} \mathrm{~B}_{2}$ & 31,58 & 71,70 & $150,58 \mathrm{bcd}$ \\
\hline $\mathrm{M}_{4} \mathrm{~B}_{0}$ & 32,70 & 73,38 & $148,95 \mathrm{bc}$ \\
\hline $\mathrm{M}_{4} \mathrm{~B}_{1}$ & 32,33 & 74,70 & $152,08 \mathrm{~b}-\mathrm{e}$ \\
\hline $\mathrm{M}_{4} \mathrm{~B}_{2}$ & 33,33 & 78,53 & $154,70 \mathrm{def}$ \\
\hline $\mathrm{M}_{5} \mathrm{~B}_{0}$ & 32,28 & 74,30 & $153,35 \mathrm{cde}$ \\
\hline $\mathrm{M}_{5} \mathrm{~B}_{1}$ & 33,25 & 75,88 & $159,05 \mathrm{fgh}$ \\
\hline $\mathrm{M}_{5} \mathrm{~B}_{2}$ & 33,83 & 78,08 & $159,85 \mathrm{f}-\mathrm{i}$ \\
\hline $\mathrm{M}_{6} \mathrm{~B}_{0}$ & 32,85 & 74,73 & $151,33 \mathrm{bcd}$ \\
\hline $\mathrm{M}_{6} \mathrm{~B}_{1}$ & 32,75 & 79,15 & $155,05 \mathrm{def}$ \\
\hline $\mathrm{M}_{6} \mathrm{~B}_{2}$ & 32,30 & 79,58 & 156,93 e-h \\
\hline $\mathrm{M}_{7} \mathrm{~B}_{0}$ & 34,75 & 80,05 & $161,33 \mathrm{~h}-\mathrm{k}$ \\
\hline $\mathrm{M}_{7} \mathrm{~B}_{1}$ & 35,60 & 82,20 & $168,38 \mathrm{~lm}$ \\
\hline $\mathrm{M}_{7} \mathrm{~B}_{2}$ & 37,25 & 85,43 & $171,43 \mathrm{~m}$ \\
\hline $\mathrm{M}_{8} \mathrm{~B}_{0}$ & 32,85 & 79,98 & $160,70 \mathrm{hij}$ \\
\hline$M_{8} B_{1}$ & 34,65 & 82,08 & $166,08 \mathrm{kl}$ \\
\hline $\mathrm{M}_{8} \mathrm{~B}_{2}$ & 34,90 & 83,05 & $168,60 \mathrm{~lm}$ \\
\hline $\mathrm{M}_{9} \mathrm{~B}_{0}$ & 35,13 & 80,78 & $160,40 \mathrm{~g}-\mathrm{j}$ \\
\hline $\mathrm{M}_{9} \mathrm{~B}_{1}$ & 34,88 & 81,30 & $165,15 \mathrm{jkl}$ \\
\hline $\mathrm{M}_{9} \mathrm{~B}_{2}$ & 35,30 & 82,53 & 165,13 i-1 \\
\hline $\mathrm{BNJ}_{0,05}$ & tn & tn & 5,31 \\
\hline
\end{tabular}

Keterangan : Angka yang diikuti oleh hurup yang sama pada kolom yang samaberbeda tidak nyata pada uji BNJ $0,05 \%$.

Tabel 9 menunjukkan bahwa tinggi tanaman mentimun tertinggi akibat interaksi perlakuan antara pemberian berbagai komposisi media tanam dengan dosis MOL bonggol pisang pada umur 28 HST terdapat pada perlakuan $M_{7} B_{2}$, secara uji $B_{0} J_{0,05}$ berbeda nyata dengan perlakuan $M_{1} B_{0}, M_{1}, B_{1}$, $M_{1} B_{2}, M_{2} B_{0}, M_{2} B_{1}, M_{2} B_{2}, M_{3} B_{0}, M_{3} B_{1}, M_{3} B_{2}, M_{4} B_{0}, M_{4} B_{1}, M_{4} B_{2}, M_{5} B_{0}, M_{5} B_{1}, M_{5} B_{2}, M_{6} B_{0}, M_{6} B_{1}$, $M_{6} B_{2}, M_{7} B_{0}, M_{8} B_{0}, M_{8} B_{1}, M_{9} B_{0}, M_{9} B_{1}, M_{9} B_{2}$. Namun tidak berbeda nyata dengan perlakuan $M_{7} B_{1}$ dan $\mathrm{M}_{8} \mathrm{~B}_{2}$.Pemberian bahan organik yang sesuai ke dalam tanah dapat membantu aktifitas mikroorganisme dalam merombak bahan organik sumber nitrogen, sehingga tanah menjadi gembur, serta meningkatkan ketersedian unsur hara nitrogen (Agus, D. 2004).

Bonggol pisang mengandung mikrobia pengurai bahan organik. Mikrobia pengurai tersebut terletak pada bonggol pisang bagian luar maupun bagian dalam (Suhastyo, 2011). Hal ini diduga bahwa kombinasi perlakuan media tanam dan MOL bonggol pisang saling mempengaruhi dalam 
menyediakan unsur hara.Bahan organik yang terdapat dalam pupuk kandang kambing dan arang sekam sudah mulai terdekomposisi oleh mikroba yang terdapat didalam MOL bonggol pisang. Hal ini sesuai dengan pendapat putra dkk (2015), bahwa bahan organik memerlukan waktu untuk menghasilkan kandungan hara pada tanah. Adapun pendapat simanungkalit dkk (2007) menyatakan bahwa penambahan mikroba mampu mempercepat proses pendekomposisian bahan organik dalam tanah.

\section{Poduksi per Plot}

Tabel 10. Rata-rata produksi perplot mentimun akibat interaksi perlakuan antara pemberian berbagai komposisi media tanam dengan dosis MOL bonggol pisang.

\begin{tabular}{|c|c|}
\hline PerlakuanKombinasi & Rata-rata Produksi per Plot $(\mathrm{kg})$ \\
\hline $\mathrm{M}_{1} \mathrm{~B}_{0}$ & $1,36 \mathrm{a}$ \\
\hline $\mathrm{M}_{1} \mathrm{~B}_{1}$ & $1,47 a b c$ \\
\hline $\mathrm{M}_{1} \mathrm{~B}_{2}$ & 1,64 cde \\
\hline $\mathrm{M}_{2} \mathrm{~B}_{0}$ & $1,39 \mathrm{a}$ \\
\hline $\mathrm{M}_{2} \mathrm{~B}_{1}$ & $1,57 \mathrm{~cd}$ \\
\hline $\mathrm{M}_{2} \mathrm{~B}_{2}$ & $1,73 \mathrm{~d}-\mathrm{g}$ \\
\hline $\mathrm{M}_{3} \mathrm{~B}_{0}$ & $1,39 \mathrm{a}$ \\
\hline $\mathrm{M}_{3} \mathrm{~B}_{1}$ & $1,42 \mathrm{ab}$ \\
\hline $\mathrm{M}_{3} \mathrm{~B}_{2}$ & $1,50 a b c$ \\
\hline $\mathrm{M}_{4} \mathrm{~B}_{0}$ & $1,50 a b c$ \\
\hline $\mathrm{M}_{4} \mathrm{~B}_{1}$ & $1,72 \mathrm{def}$ \\
\hline $\mathrm{M}_{4} \mathrm{~B}_{2}$ & $1,90 \mathrm{~g}-\mathrm{k}$ \\
\hline $\mathrm{M}_{5} \mathrm{~B}_{0}$ & $1,89 \mathrm{f}-\mathrm{j}$ \\
\hline $\mathrm{M}_{5} \mathrm{~B}_{1}$ & $1,98 \mathrm{i}-\mathrm{m}$ \\
\hline $\mathrm{M}_{5} \mathrm{~B}_{2}$ & $2,07 \mathrm{k}-\mathrm{o}$ \\
\hline $\mathrm{M}_{6} \mathrm{~B}_{0}$ & $1,79 \mathrm{f}-\mathrm{i}$ \\
\hline $\mathrm{M}_{6} \mathrm{~B}_{1}$ & $1,83 \mathrm{f}-\mathrm{i}$ \\
\hline $\mathrm{M}_{6} \mathrm{~B}_{2}$ & 2,04 j-n \\
\hline $\mathrm{M}_{7} \mathrm{~B}_{0}$ & $1,82 \mathrm{f}-\mathrm{i}$ \\
\hline $\mathrm{M}_{7} \mathrm{~B}_{1}$ & $1,90 \mathrm{~g}-\mathrm{k}$ \\
\hline $\mathrm{M}_{7} \mathrm{~B}_{2}$ & 2,20 nop \\
\hline $\mathrm{M}_{8} \mathrm{~B}_{0}$ & $2,081-0$ \\
\hline $\mathrm{M}_{8} \mathrm{~B}_{1}$ & $2,12 \mathrm{mno}$ \\
\hline $\mathrm{M}_{8} \mathrm{~B}_{2}$ & $2,30 \mathrm{p}$ \\
\hline $\mathrm{M}_{9} \mathrm{~B}_{0}$ & $1,91 \mathrm{~h}-1$ \\
\hline $\mathrm{M}_{9} \mathrm{~B}_{1}$ & $1,97 \mathrm{i}-\mathrm{n}$ \\
\hline $\mathrm{M}_{9} \mathrm{~B}_{2}$ & $2,24 \mathrm{op}$ \\
\hline $\mathrm{BNJ}_{0,05}$ & 0,17 \\
\hline
\end{tabular}

Keterangan : Angka yang diikuti oleh hurup yang sama pada kolom yang sama berbeda tidak nyata pada uji $\mathrm{BNJ}_{0,05 \%}$.

Data hasil analisi ragam pengamatan produksi per plot mentimun akibat interaksi perlakuan antara pemberian berbagai komposisi media tanam dengan dosis MOL bonggol pisang berpengaruh nyata. disajikan pada Tabel 10. Tabel 10 menunjukkan bahwa produksi perplot mentimun tertinggi akibat interaksi perlakuan antara pemberian berbagai komposisi media tanam dengan dosis $\mathrm{MOL}$ bonggol pisang terbaik terdapat pada perlakuan $\mathrm{M}_{8} \mathrm{~B}_{2}$ dimana secara uji $\mathrm{BNJ}_{0,05}$ berbeda nyata dengan perlakuan $\mathrm{M}_{1} \mathrm{~B}_{0}, \mathrm{M}_{1} \mathrm{~B}_{1}, \mathrm{M}_{1} \mathrm{~B}_{2}, \mathrm{M}_{2} \mathrm{~B}_{0}, \mathrm{M}_{2} \mathrm{~B}_{1}, \mathrm{M}_{2} \mathrm{~B}_{2}, \mathrm{M}_{3} \mathrm{~B}_{0}, \mathrm{M}_{3} \mathrm{~B}_{1}, \mathrm{M}_{3} \mathrm{~B}_{2}, \mathrm{M}_{4} \mathrm{~B}_{0}, \mathrm{M}_{4} \mathrm{~B}_{1}, \mathrm{M}_{4} \mathrm{~B}_{2}, \mathrm{M}_{5} \mathrm{~B}_{0}$, $\mathrm{M}_{5} \mathrm{~B}_{1}, \mathrm{M}_{5} \mathrm{~B}_{2}, \mathrm{M}_{6} \mathrm{~B}_{0}, \mathrm{M}_{6} \mathrm{~B}_{1}, \mathrm{M}_{6} \mathrm{~B}_{2}, \mathrm{M}_{7} \mathrm{~B}_{0}, \mathrm{M}_{7} \mathrm{~B}_{1}, \mathrm{M}_{8} \mathrm{~B}_{0}, \mathrm{M}_{8} \mathrm{~B}_{1}, \mathrm{M}_{9} \mathrm{~B}_{0}$ dan $\mathrm{M}_{9} \mathrm{~B}_{1}$, namun tidak berbeda nyata dengan perlakuan $M_{7} B_{2}$, dan $M_{9} B_{2}$. Penambahan $M O L$ sebagai dekomposer bertujuan untuk mempercepat proses pengomposan walaupun bahan pengomposan sudah mengandung mikrobia khususnya yang berperan dalam perombakan bahan kimia (Widiawati,2005). 
Hal ini diduga bahwa dengan interaksi perlakuan media tanam dan MOL bonggol pisang mampu memaksimalkan unsur hara yang terdapat didalam bahan organik akibat aktifitas hidup mikroba didalam media tanam yang digunakan.. Hadisuwito, 2008 menyatakan proses pengomposan memerlukan aktivator sebagai dekomposer dalam proses dekomposisi bahan organik kompleks yang dilakukan oleh mikroorganisme sehingga menjadi bahan organik sederhana yang kemudian mengalami mineralisasi sehingga menjadi tersedia dalam bentuk mineral yang dapat diserap oleh tanaman atau organisme lain.

\section{Kesimpulan}

\section{KESIMPULAN DAN SARAN}

1. Hasil penelitian menunjukkan bahwa komposisi media tanam berpengaruh nyata terhadap parametertinggi tanaman, panjang buah, diameter buah, dan produksi per plot. Hasil terbaik diperoleh pada perlakuan $\mathrm{M}_{8}$ (tanah + pupuk kandang kambing + pasir).

2. Pemberian MOL bonggol pisang berpengaruh nyata terhadap parameter tinggi tanaman, panjang buah, diameter buah, dan produksi per plot. Hasil terbaik diperoleh pada pemberian MOL bonggol pisang perlakuan $\mathrm{M}_{2}$ (300 $\mathrm{ml} /$ liter air).

3. Interaksi perlakuan media tanam dengan pemberian MOL bonggol pisang berpengaruh nyata pada parameter tinggi tanaman umur $28 \mathrm{HST}$, dan produksi perplot, namun tidak berpengaruh nyata terhadap parameter tinggi tanaman umur 14 dan 21 HST, panjang buah, diameter buah.Interaksi terbaik terhadap parameter pengamatan dijumpai pada kombinasi perlakuan media tanam dan pemberian MOL bonggol pisang $\left(\mathrm{M}_{8} \mathrm{~B}_{2}\right)$

\section{Saran}

1. Sesuai dengan hasil penelitian ini untuk mendapatkan pertumbuhan dan produksi tanaman mentimun yang baik dalam budidaya menggunakan poly bag, disarankan menggunakan media tanam tanah + pupuk kandang kambing + pasir dan pemberian MOL boggol pisang dengan konsentrasi $300 \mathrm{ml} / \mathrm{lt}$ air yang dilakukan bersamaan.

\section{DAFTAR PUSTAKA}

Agus, D. 2004. Berbagai Jenis Media Tanam dan Penggunaannya. Penebar Swadaya. Jakarta.

Agustina, L. 2008. Dasar Nutrisi Tanaman.: Rineka Cipta. Jakarta.

Campbell. 2003. Biologi. Penerbit Erlangga. Jakarta.

Ghani, P. dan Morsono. 2002. Petunjuk Penggunaan Pupuk. Penebar Swadaya. Jakarta.

Hakim, N., M. A. Pulung, M. Y. Nyakpa. 2006. Pupuk dan Pemupukan. Andalas University Press. Padang.

Hanafiah, 2005. Dasar-Dasar Ilmu Tanah: Raja Grafindo Persada. Jakarta.

Handiyan,2013. Penggunaan Pasir dan Serat Kayu Aren sebagai Media Tanam Terong dan Tomat dengan Sistem Hidroponik. Jurnal Agrosains 15(2): 36-40, 2013; ISSN: 1411-5786.

Kusuma, A. H., M. Izzati, dan E. Saptiningsih. 2013. Pengaruh Penambahan Arang dan Abu Sekam dengan Proporsi yang Berbeda Terhadap Permeabilitas dan Porositas Tanah Liat serta Pertumbuhan Kacang Hijau (Vigna radiata L.). Jurnal Anat \& Fisiol. XXI (1): 1-9.

Madjid B. Damanik 2010. Kesuburan Tanah dan Pemupukan. USU Press, Medan.

Mapegau. 2010. Pengaruh Pemupukan N dan P terhadap Pertumbuhan dan Hasil Tanaman Jagung.Jurnal Penelitian Universitas Jambi: Seri Sains. 12(2): 33-36.

Maulana, A. Azies, dan T. Soemarah. 2010. Pengaruh dosis Pupuk Kalium dan Pupuk Kandang Kambing Terhadap Pertumbuhan dan Hasil Jagung Hibrida (Zea mays L.) Varietas Pioneer 21. Jurnal Agrineca 10(2):135-150. 
Mayadewi, A. 2007. Pengaruh Jenis Pupuk Kandang dan Jarak Tanam terhadap Pertumbuhan Gulma Hasil Jagung Manis. Jurnal Agritrop, 26 (4) : 153-159 ISN

Muhshin, M.M.B., E.H. Bachtiar., Fauzi., Sarifuddin dan H. Hamidah. 2006. Kesuburan Tanah dan Pemupukan. USU Press, Medan

Putra, A. D., M. M. B. Damanik, dan H. Hanum. 2015. Aplikasi pupuk urea dan pupuk kandang kambing untuk meningkatkan $\mathrm{N}$-total pada tanah inceptisol kwala bekala dan kaitannya terhadap pertumbuhan tanaman jagung (Zea mays L.). Jurnal Online Agroekoteknologi, 3 (1) : $128-135$.

Soegiman, W. dan D.A. Suriadikarta. 2002. Pengaruh pupuk organik granul dan curah terhadap sifat kimia tanah, pertumbuhan dan produksi padi sawah. Dalam Prosiding HITI X di Surakarta,.

Suhastyo, A A. 2011.. Studi Mikrobiologi dan Sifat Kimia Mikroorganisme Local yang Digunakan pada Budidaya Padi Metode SRI (System of Rice Intensification). Tesis. Pasca sarjana. Institut Pertanian Bogor.

Supriyanto dan F. Fiona. 2010. Pemanfaatan Arang Sekam untuk Memperbaiki Pertumbuhan Semai Jabon (Anthocephalus cadamba) pada Media Subsoil. Jurnal Silvikultur Tropika, 01 (01): 24-28.

Suriadikarta, Didi Ardi., Simanungkalit, R.D.M. (2007). Pupuk Organik dan Pupuk Hayati. Balai Besar Penelitian dan Pengembangan Sumber daya Lahan Pertanian. Jawa Barat.

Widowati, L.R., Sri Widati, U. Jaenudin, dan W. Hartatik. 2005. Pengaruh Kompos Pupuk Organik yang Diperkaya dengan Bahan Mineral dan Pupuk Hayati terhadap Sifat-sifat Tanah, Serapan Hara dan Produksi Sayuran Organik. Laporan Proyek Penelitian Program Pengembangan Agribisnis, Balai Penelitian Tanah.

Wijoyo, P.M. 2012. Budidaya Mentimun yang Lebih Menguntungkan. Pustaka Agro Indonesia. Jakarta.

Wiryanta. W dan Bernardinus .T. 2002. Bertanam Cabai Pada Musim Hujan. Agromedia Pustaka. Jakarta. 